\title{
Constraints of Ruminant Rearing and Ethno-veterinary Practice Against African Animal Trypanosomosis in the Pastoral Area of Gaongho in Burkina Faso
}

\author{
Zongo André1, Kaboré Adama ${ }^{1,}$ *, Traoré Aristide ${ }^{2}$, Zabré Géneviève $^{1}$, Traoré Amadou ${ }^{1}$, \\ Tamboura Hamidou Hamidou ${ }^{1}$, Belem Adrien Marie Gaston ${ }^{3}$ \\ ${ }^{1}$ Département Productions Animales, Institut de l'Environnement et de Recherches Agricoles, Ouagadougou, Burkina Faso \\ ${ }^{2}$ Institut de Recherche en Sciences de la Sante, Ouagadougou, Burkina Faso \\ ${ }^{3}$ Institut du Développement Rural, Université Polytechnique de Bobo-Dioulasso, Burkina Faso
}

Email address:

andrezongobf@yahoo.fr (Z.André), ade1_bf@yahoo.fr (K. Adama), aristide_hami@yahoo.fr (T. Aristide), gnvivezabr@yahoo.com (Z. Géneviève), traore_pa@yahoo.fr (T. Amadou),hh_tamboura@hotmail.com (T. H. Hamidou), belemadrien@yahoo.fr (B. A. M. Gaston)

${ }^{*}$ Corresponding author

\section{To cite this article:}

Zongo André, Kaboré Adama, Traoré Aristide, Zabré Géneviève, Traoré Amadou, Tamboura Hamidou Hamidou, Belem Adrien Marie Gaston. Constraints of Ruminant Rearing and Ethno-veterinary Practice Against African Animal Trypanosomosis in the Pastoral Area of Gaongho-in Burkina Faso. Animal and Veterinary Sciences. Vol. 5, No. 1, 2017, pp. 1-7. doi: 10.11648/j.avs.20170501.11

Received: January 2, 2017; Accepted: January 12, 2017; Published: February 6, 2017

\begin{abstract}
In rural area of Burkina Faso, health management of domestic animals is a constant concern for low-income farmers. In this context, an ethno-veterinary survey was conducted among 62 farmers of ruminant in the pastoral area of Gaongho in Bazèga province to understand the rearing practice, to identify the main constraints of and the practices used against African trypanosomosis. For this, data were collected between March to June 2014 using a structured questionnaire and analyzed by descriptive statistics such as mean, frequency and percentages. The results showed that respondents were $48.3 \%$ literate and mainly of Fulani ethnic with an average age of 45 years. The main constraints of ruminant rearing for farmers are diseases (86.2\%), particularly African Animal Trypanosomosis which is the most dominant (96.7\%). To control this pathology, farmers practice modern $(100 \%)$ and traditional $(35.4 \%)$ medicine. Seventeen traditional herbal remedies are used to control trypanosomosis of ruminants in the area. Their modes of preparation and administration to ruminants are described according to surveyed farmers.
\end{abstract}

Keywords: Animal Trypanosomosis, Ethnoveterinary, Pastoral Area, Ruminant, Burkina Faso

\section{Introduction}

In sub-Saharan area of Africa, about $80 \%$ of the population lives in rural areas and depend on agriculture for survival [1]. In those countries where per capita income is often very low, livestock represents about 10 to $20 \%$ of GDP and is therefore a vital source of food, income and aid to agriculture by animal traction and organic manure [2].

In Burkina Faso, the livestock sector contributed to GDP between $18.3 \%$ and $19.5 \%$ over the period from 2001 to 2008 [3]. It is the primary source of monetary income for households for the largest proportion of poor people after agriculture in rural farms where animals, including ruminants translates into the ease of the family. However, the rearing of these animals is confronted to health constraints which disrupt the real expression of their performances. Among these, African Animal Trypanosomosis (AAT) constitute a real constraint that preoccupies rural livestock farmers with low-income, because AAT negatively affect the productivity of their animals and consequently their incomes. It is one of the most important vector-borne diseases of tsetse flies in sub-Saharan area of Africa. With the current knowledge, the fight against this scourge is difficult because the prospects of development of a vaccine are still remote because of the great antigenic variability of the trypanosomes. Control efforts 
include anti-vector control and control of the parasite's animal reservoir using trypanocidal drugs in chemotherapy and chemoprophylaxis that are currently the most common means used by many famers to control AAT [4]. However, the use of these trypanocidal drugs relies on old molecules and reduced in number. Moreover, their repeated and sometimes abnormal use (wrong dosage) and their authenticity have led to the emergence of trypanosome resistance to trypanocidal drugs (chemoresistance) reported in many endemic African countries [5]. It is therefore important to carry out investigations in order to find a solution easily accessible to livestock farmers and sustainable over time.

This study was conducted in the pastoral area of Gaongho in the south-central region of Burkina Faso to understanding the traditional practices of animal health management in general and AAT in particular. The main objective is to contribute to the development of animal husbandry by improving animal health conditions.

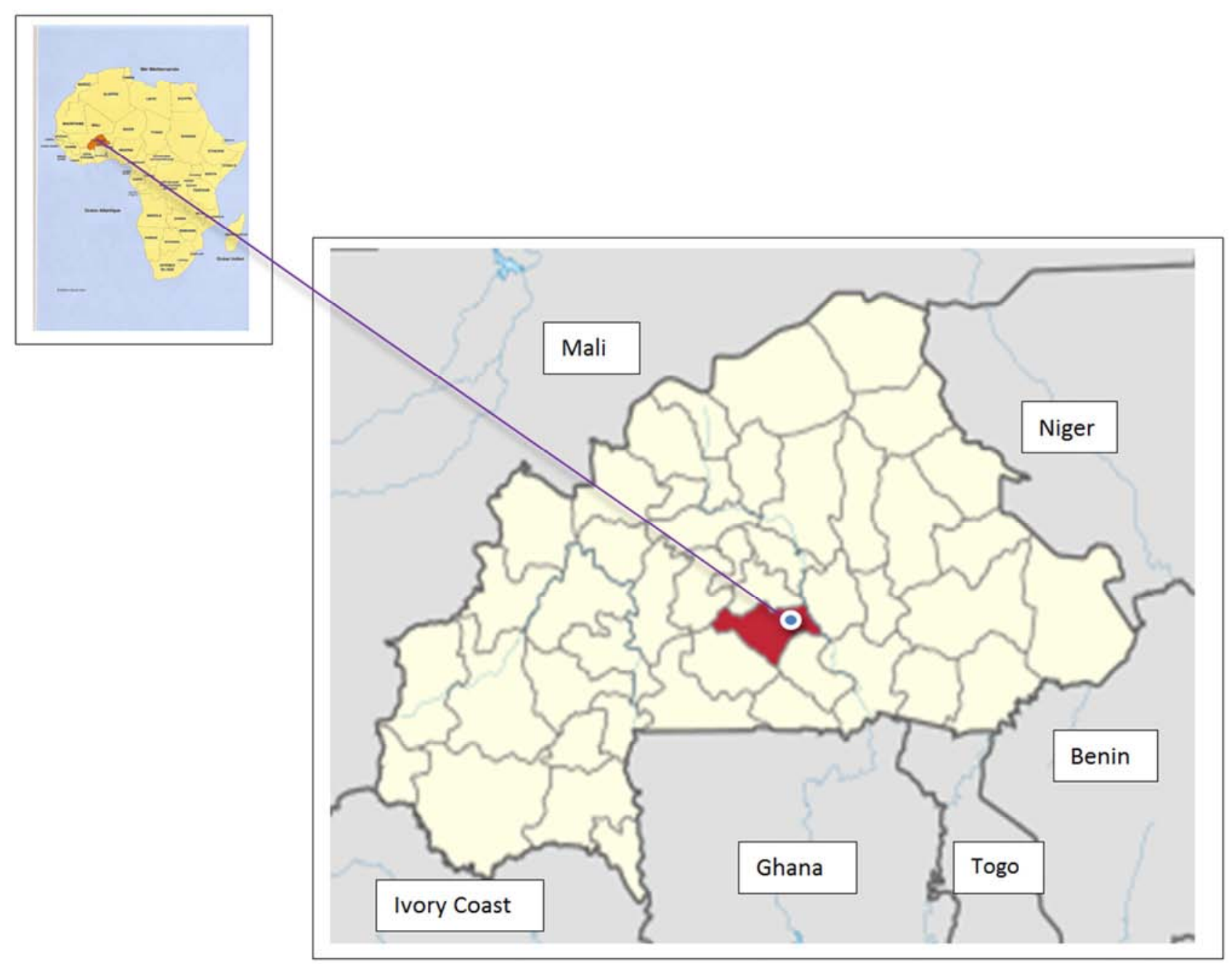

Figure 1. Localization of study area $\left(11^{\circ} 56^{\prime}\right.$ and $12^{\circ} 04^{\prime}$ north latitude, $01^{\circ} 03$ meridians and $01^{\circ} 09$ west longitude) in Burkina Faso.

\section{Materials and Methods}

\subsection{Study Area}

The study was conducted in pastoral area of Gaongho that covers 6762 ha (Figure 1). This is an area which is composed of a set of rural land areas delineated and managed for pastoral activities in combination with vegetable and forest productions. The climate of the area is a type northern Sudan characterized by the alternation of a rainy season (May to October) and a dry season (November to April). Temperatures vary greatly during the year with an average of $30^{\circ} \mathrm{C}$ while the maximum temperature reached $38^{\circ} \mathrm{C}$ during the hottest times of the year. The vegetation of wooded savannah with natural vegetation still present in the village forests and relics of forest galleries along the main lowlands. The main encountered plant species are Parkia biglobosa, Tamarindus indica, Lannea acida, Lannea microcarpa, Sclérocarya birrea, Piliostigma sp., Guiera senegalensis, Mitragyna inermis, etc. [6].

\subsection{Survey Methodology}

The study was conducted from March to June 2014. Sensitization was first conducted through meetings with farmers and the pastoral zone management committee in the field to discuss the objectives of the study. Then sixty-two 
(62) farmers were randomly selected to be surveyed through survey forms containing a set of formal questions to facilitate accurate answers. The requested information relates to the profiles of farmers, their perceptions about production constraints and major diseases of ruminants, trypanosomes and control practices of these parasites. The questionnaire was administered individually and according to the convenience of the respondents.

\subsection{Statistical Analyses}

Collected data were stripped manually and then entered in Excel before performing descriptive analyzes by calculating the frequencies and percentages using Statview for Windows, version 4.57 .

\section{Results}

Respondents were all male and Fulani ethnic group. They were mainly farmers (87\%) and agro-pastoralists (12.9\%) with a mean age of $45 \pm 13$ years. $48.3 \%$ of them were literate in French (3.2\%), Fulfuldé (35.4\%), Mossi (6.4\%) and arabic $(33.8 \%)$. All the people surveyed use extensive farming system or shelter animals bred are made with tree branches. The numbers of ruminants per farmer vary from 12 to 200 cattle ( $100 \%$ of respondents), from 0 to 200 for sheep $(93.5 \%)$ and from 0 to 90 goats $(93.5 \%)$.

Figure 2 presents the main constraints identified by farmers in the rearing of ruminants in the study area $f$ Gaongho. Diseases are the main constraints $(86.2 \%)$ followed of watering difficulties in the cattle herd $(75.8 \%)$ and thefts in small ruminant herd $(61.2 \%)$.

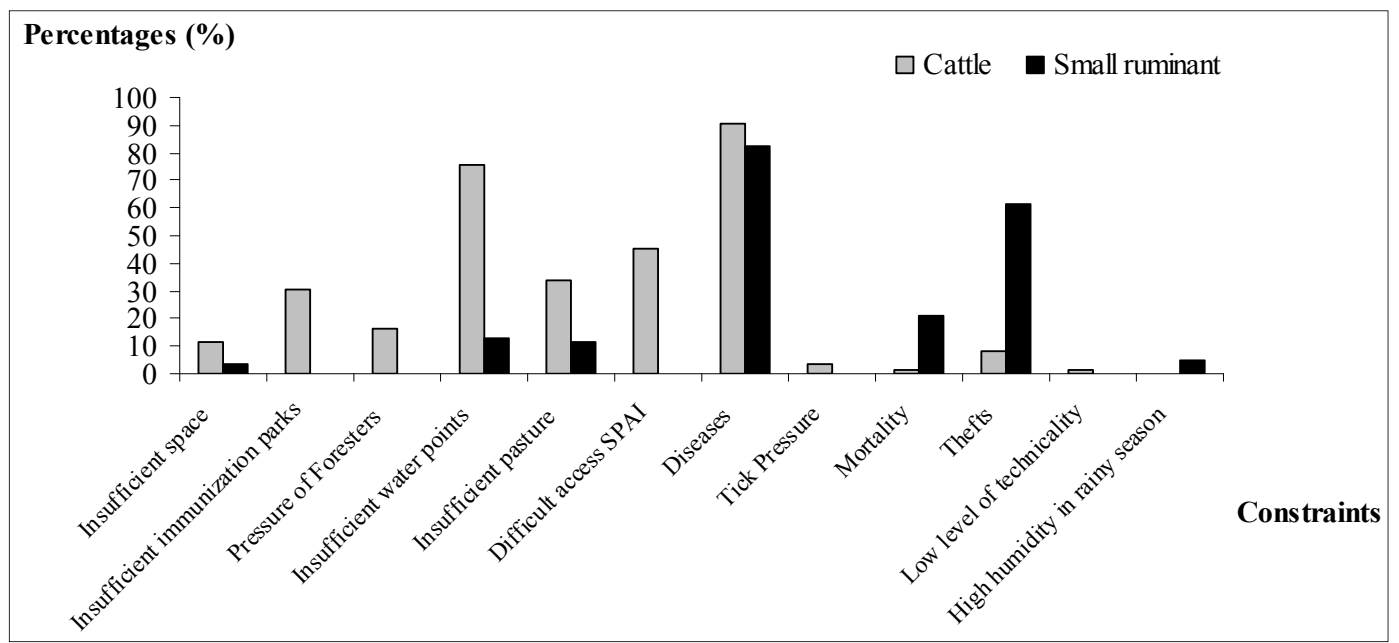

Figure 2. Main constraints of ruminant rearing in pastoral areas of Gaongho.

Figure 3 shows 14 diseases identified by surveyed farmers and among which parasitic diseases are the most dominant, including AAT (96.7\%) and gastrointestinal parasitism (58\%).

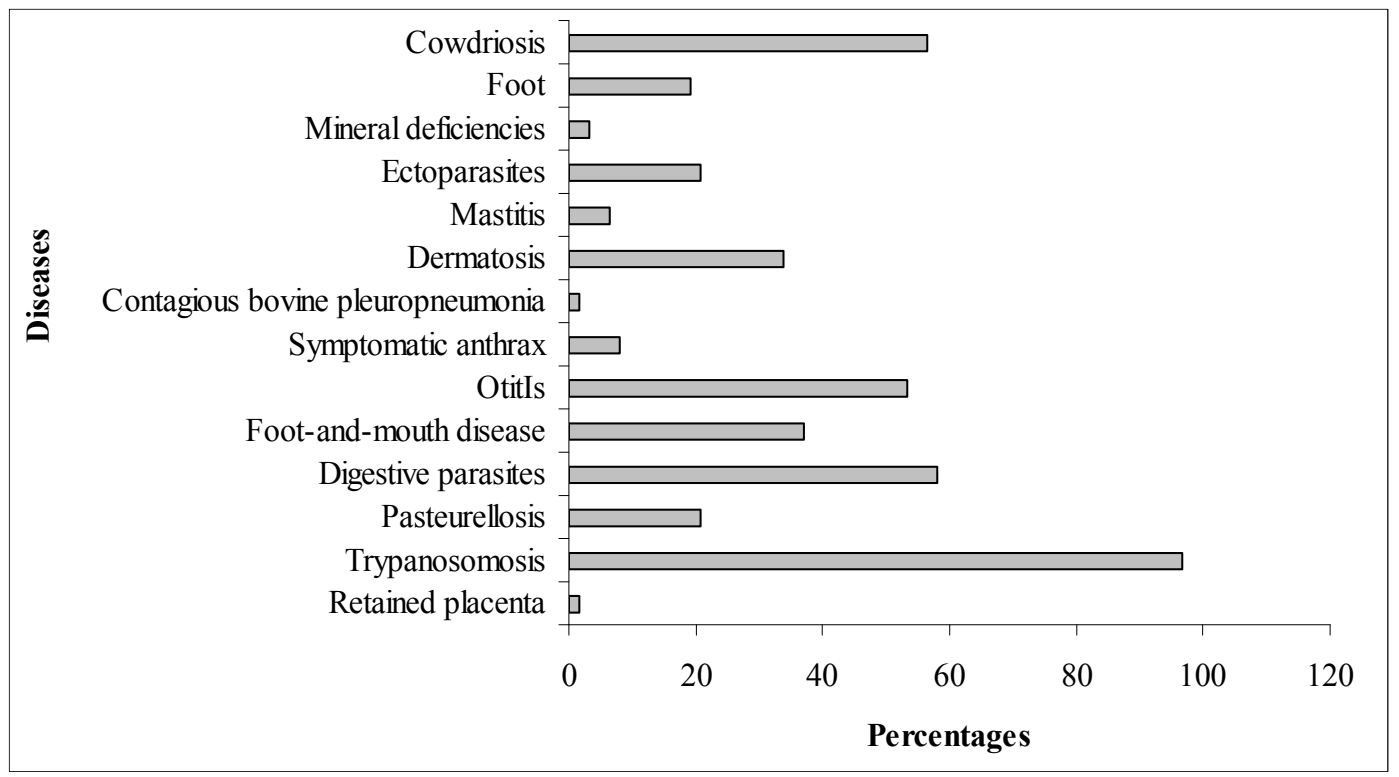

Figure 3. Main diseases of ruminants in the pastoral area of Gaongho. 
In most cases, farmers describe animal disease by its manifestations by considering the clinical signs presented by animal. Figure 4 presents the main signs of disease according the respondents. Anorexia (96.7\%), stitched hairs (50\%), diarrhea (38.7\%), weight loss $(32.2 \%)$ were the most pronounced.

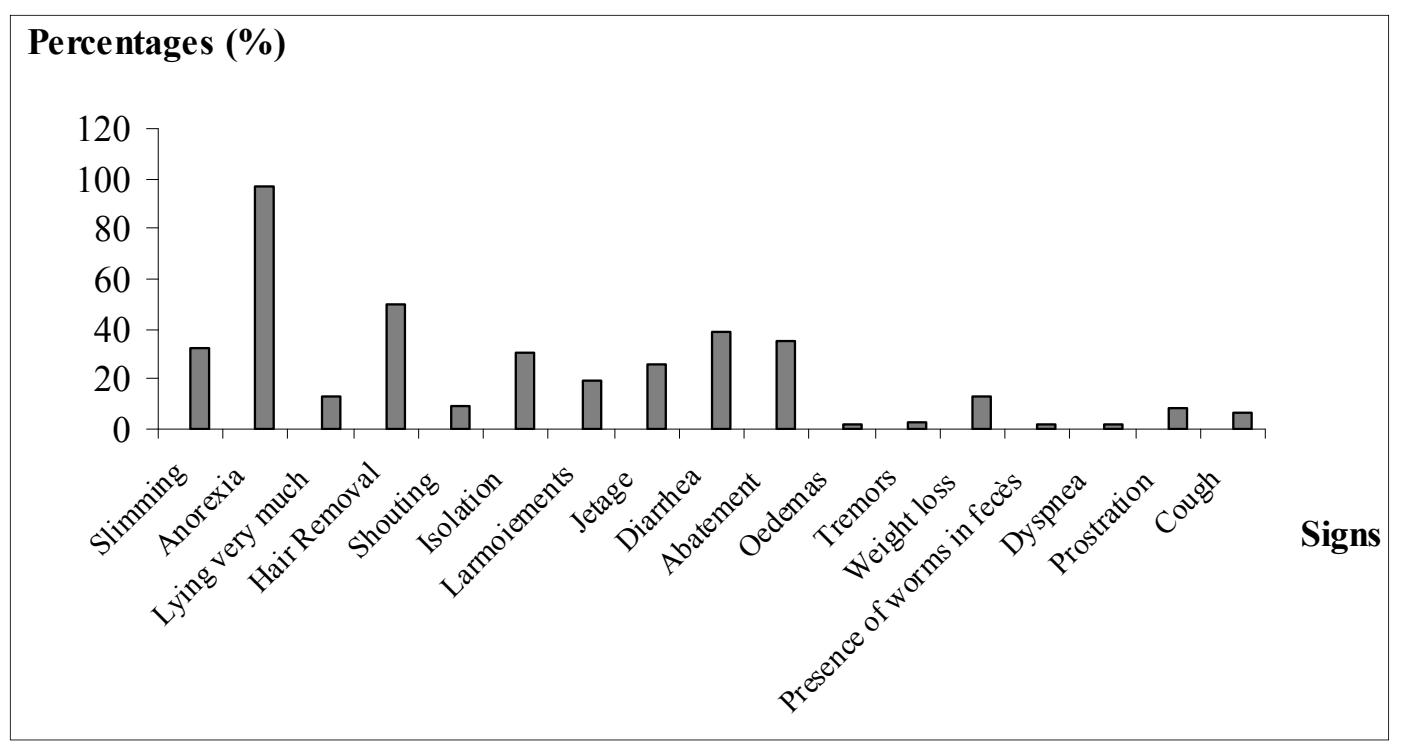

Figure 4. Signs statements by farmers in the description of animal diseases.

For $56.4 \%$ of respondents, the maximum infestation level of ruminants to AAT occurs during the winter season (July to August) because of the abundance of vegetation that is favorable to the development and survival of the vectors, transmitting the trypanosomes, pathogen agents of the disease. The consequences of AAT are multiple and affect both production and productivity of ruminants and the costs they incur (cost of treatment products and veterinary acts) for all farmers. Animal mortalities are the most severe consequences of disease in cattle and small ruminant (100\%) herds (Figure
5). To treat or control AAT, all respondents use conventional products available from public and private veterinary officers. Conventional products used are isometamidium chloride (Sécuridium, Trypamidium) and diminazene (Survidim, Vériben). However, $35.4 \%$ of respondents practice traditional veterinary medicine to treat their sick animals suffering of AAT. According to these farmers, this action is explained by the high cost of modern treatments, often unavailability of veterinary officers and inaccessibility of farmers' camps or parks to periods of the year.

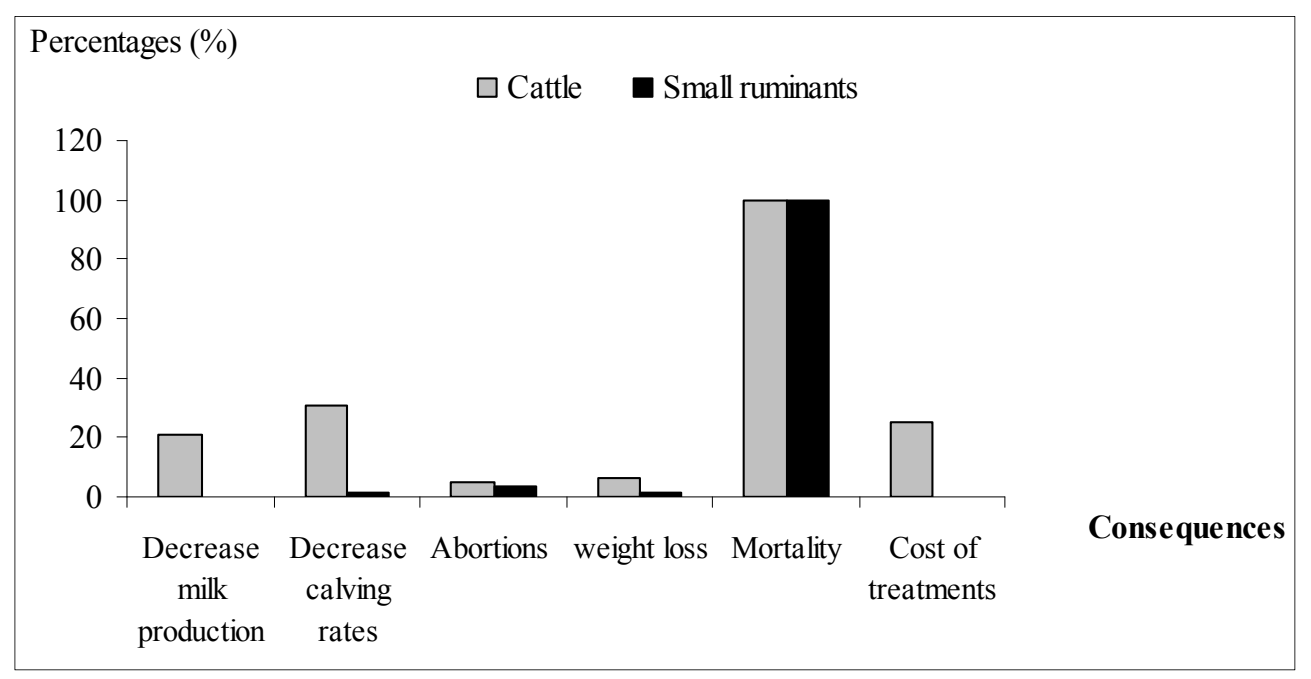

Figure 5. Main consequences of AAT on ruminants in the pastoral zone according the farmers.

All respondents treat their animals against AAT with conventional products available from public and private veterinary officers. Conventional products used primarily are isometamidium chloride (Securidium, Trypamidium) and diminazene (Survidim, Vériben). However, 35.4\% of respondents practice traditional veterinary medicine to treat their sick animals suffering of AAT. According to these farmers, this action is explained by the high cost of modern treatments, often unavailability of veterinary officers and inaccessibility of farmers' camps or parks to periods of the year. 
Traditional remedies used in treatment of animal trypanosomosis in pastoral areas of Gaongho are composed of medicinal plants (Table 1), often combined with other ingredients (chili, soumbala) to obtain the final product. A total of seventeen (17) remedies have been indicated by the farmers interviewed as effective against AAT in ruminants. Natural plants involved in these remedies are from eleven (11) families and the most represented are Mimosaceae $(27.2 \%)$ followed by Anacardiaceae, the Capparacées and Combretaceae (18.1\% respectively).

Main parts of the plants used in the preparation of these traditional drugs are the leaves, roots and barks of stems. The modes of preparation and administration are shown in table 1. The preparation is repeated very often and treatment time ranges from one to seven days according remedies and severity of the disease.

\section{Discussion}

In Burkina Faso, the majority of the population lives in rural areas where their main activities are based on agriculture and livestock to fight food insecurity and poverty. The low incomes that the producers get from these two activities led them to practice traditional medicine to treat themselves and their animals, making the ethno-veterinary a reality in farmer context of the country [7, 8]. Unfortunately, this traditional veterinary knowledge in the pastoral area of Gaongho are transmitted from generation to generation, from mouth to hear, from father to son, without written although some farmers are literate (in French, Fulfuldé, Mossi and Arabic). They are thus subject to a gradual disappearance over time if appropriate measures are not taken to collect these rich traditional skills to their sustainability.

Furthermore, our study is original in the context of Burkina Faso because no similar work has been done before in the pastoral areas of the country with the aim of documenting traditional veterinary practices..

Socio-economic analysis of the farmers surveyed in the study revealed the absence of women, which could be explained by the fact that they are not animals' owners in the pastoral area. One would then think that women rarely own animals in Fulani people because all the surveyed farmers were mainly of Fulani ethnicity. Similar observation was made by Gnanda [9] in the Sahelian region of the country where the auteur observed only one woman out of 150 goat farmers.

The relatively advanced age of farmers of the study allows us to suppose that they have had time to experiment the efficacy of the traditional veterinary knowledge they practice on their animals in view of the importance of animals they possess. Signs or similar or related groups of signs reported by farmers are especially characteristic of parasitic diseases, in particular of the trypanosomosis which seems the dominant pathology in the area according to farmers. These signs are almost similar to those reported by cattle breeders to diagnose trypansomosis in Uganda [10].

Farmers report that the rainy season is the period when the level of infestation of the animals is high. This finding indicates that farmers are aware that the presence and development of intermediate hosts (tsetse flies) that are the cause of the disease, depending on climatic conditions (hydrographic network, vegetation and temperature) as reported by Chartier et al. [11]. Negative impacts decry by respondents are consistent with existing scientific knowledge relating to constitute a limiting factor in livestock production. Indeed, it is estimated that more than 50 million cattle and 230 million small ruminants are exposed to the risk of AAT in sub-Saharan Africa [12, 4], which nevertheless offer strong fodder and agricultural potentialities yet.

The main impacts of trypanosomosis are an increased mortality rate that can reach $50 \%$ infertility, recurrent abortions and reduced milk production (10-20\%), meat (5$30 \%$ ) and animal traction (33\%) [13]. For others, disease would lead to disturbances in reproduction [14], productivity losses by falling milk production of 2 to $26 \%$ of and animal labor power to $38 \%$ [15] and abortions varying between $6 \%$ and $19 \%$ in high risk areas $[14,16,17]$. In addition, she is an obstacle to the genetic improvement of local breeds by the introduction of exotic animal.

For the treatment or control of ruminant trypanosomosis, the reasons mentioned by our farmers for using the traditional pharmacopoeia corroborate the observations made by Kaboré et al. [18] in the region of the Central Plateau of the country. In this region, farmers use anthelmintic medicinal plants to treat small ruminants. To these reasons, we could add the trypanosome resistance to the conventional trypanocide drugs that is increasingly reported worldwide [19] and in Burkina Faso [20]. This fact leads the scientific community and farmers to look at other alternatives of treatments of AAT through the use of medicinal plants that are cultural values generally derived from local natural resources of rural communities.

Table 1. Traditional remedies used in the treatment of AAT in pastoral area of Gaongho.

\begin{tabular}{|c|c|c|c|c|c|}
\hline \multicolumn{2}{|l|}{ Plants } & \multirow[b]{2}{*}{ Used Parts } & \multirow[b]{2}{*}{ Preparation } & \multirow{2}{*}{$\begin{array}{l}\text { Modes of } \\
\text { administration }\end{array}$} & \multirow[b]{2}{*}{$\begin{array}{l}\text { Duration of } \\
\text { treatment (days) }\end{array}$} \\
\hline Species (families) (citation) & $\begin{array}{l}\text { Local name } \\
\text { (in mooré) }\end{array}$ & & & & \\
\hline Mitragyna inermis (Rubiacées) (9,5\%) & Yilga & leaves & $\begin{array}{l}\text { Boil well then let cool or } \\
\text { crush, then add a little clean } \\
\text { water and sift }\end{array}$ & $\begin{array}{l}\text { Drink twice a day } \\
\text { (morning and } \\
\text { evening) }\end{array}$ & 7 \\
\hline $\begin{array}{l}\text { Detarium microcarpum } \\
\text { (Caesalpiniacées) }(4,7 \%)+\text { Boswellia } \\
\text { dalzelii (Burseracées) }(4,7 \%)\end{array}$ & $\begin{array}{l}\text { Kaguedga }+ \\
\text { Koundryingo }\end{array}$ & $\begin{array}{l}\text { Bark or } \\
\text { leaves }\end{array}$ & Boil well and let cool & drink once a day & $2-3$ \\
\hline $\begin{array}{l}\text { Acacia macrostachya (Mimosacées) } \\
(4,7 \%)\end{array}$ & $\begin{array}{l}\text { Zamnega ou } \\
\text { Kardga }\end{array}$ & leaves & $\begin{array}{l}\text { Pound well then, add a little } \\
\text { clean water and sift }\end{array}$ & drink once a day & 2 \\
\hline
\end{tabular}




\begin{tabular}{|c|c|c|c|c|c|}
\hline \multicolumn{2}{|l|}{ Plants } & \multirow[b]{2}{*}{ Used Parts } & \multirow[b]{2}{*}{ Preparation } & \multirow{2}{*}{$\begin{array}{l}\text { Modes of } \\
\text { administration }\end{array}$} & \multirow{2}{*}{$\begin{array}{l}\text { Duration of } \\
\text { treatment (days) }\end{array}$} \\
\hline Species (families) (citation) & $\begin{array}{l}\text { Local name } \\
\text { (in mooré) }\end{array}$ & & & & \\
\hline $\begin{array}{l}\text { Boscia senegalensis (Capparacées) } \\
(4,7 \%)\end{array}$ & Lamboaye & leaves & $\begin{array}{l}\text { Pound well then, add a little } \\
\text { clean water and sift }\end{array}$ & drink once a day & $2-3$ \\
\hline $\begin{array}{l}\text { Vitellaria paradoxa (Sapotacées) } \\
(9,5 \%)\end{array}$ & Taanga & $\begin{array}{l}\text { Young leaves } \\
\text { + buds }\end{array}$ & $\begin{array}{l}\text { Pound well then, add a little } \\
\text { clean water and sift }\end{array}$ & $\begin{array}{l}\text { Drink } 1 \text { to } 2 \text { times a } \\
\text { day }\end{array}$ & $2-3$ \\
\hline $\begin{array}{l}\text { Guiera senegalensis (Combretacées) } \\
(9,5 \%)\end{array}$ & Wiliwiiga & leaves & Pile, add clean water and sift & drink once a day & $1-2$ \\
\hline $\begin{array}{l}\text { Acacia sieberiana (Mimosacées) } \\
(4,7 \%)\end{array}$ & Gonponsogo & bark & Boil well then let cool & drink once a day & $2-3$ \\
\hline $\begin{array}{l}\text { Lannea microcarpa (Anacardiacées) } \\
(4,7 \%)\end{array}$ & Sanbga & leaves & Boil well then let cool & drink once a day & 1 \\
\hline $\begin{array}{l}\text { Parkia biglobosa (Mimosacées) } \\
(4,7 \%)\end{array}$ & Roanga & bark & $\begin{array}{l}\text { Boil well, add a little Shea } \\
\text { butter and let cool }\end{array}$ & drink once a day & $2-3$ \\
\hline \multirow{2}{*}{$\begin{array}{l}\text { Balanites aegyptiaca (Balanitacées) } \\
(14,2 \%)\end{array}$} & \multirow[t]{2}{*}{ Kèglega } & bark & $\begin{array}{l}\text { Put in a pot, then add an } \\
\text { embers on it }\end{array}$ & $\begin{array}{l}\text { Fumigation } \\
\text { (especially in calves), } \\
1 \text { to } 2 \text { times a day }\end{array}$ & $1-2$ \\
\hline & & young plants & $\begin{array}{l}\text { Boil well, add a little Shea } \\
\text { butter and let coo }\end{array}$ & drink once a day & $2-3$ \\
\hline \multirow[t]{2}{*}{$\begin{array}{l}\text { Capparis sepiaria (Capparacées) } \\
(9,5 \%)\end{array}$} & \multirow[t]{2}{*}{ Silkoatga } & leaves & $\begin{array}{l}\text { Thoroughly pound with a } \\
\text { little chili and "soumbala", } \\
\text { then put in water }\end{array}$ & drink once a day & $2-3$ \\
\hline & & Roots & Pound well, then put in water & drink once a day & $2-3$ \\
\hline $\begin{array}{l}\text { Anogeissus leiocarpus } \\
\text { (Combretacées) }(4,7 \%)\end{array}$ & Siiga & leaves & Pile, add clean water and sift & drink once a day & 1 \\
\hline $\begin{array}{l}\text { Vitellaria paradoxa (Sapotacées) } \\
(4,7 \%)+\text { Pterocarpus erinaceus } \\
\text { (Fabacées) }(4,7 \%)\end{array}$ & $\begin{array}{l}\text { Taanga }+ \\
\text { Noinga }\end{array}$ & bark & Boil well then let cool & $\begin{array}{l}1 \text { to } 2 \text { times the same } \\
\text { day }\end{array}$ & 1 \\
\hline Lannea acida (Anacardiacées) $(4,7 \%)$ & Sanbtoulga & bark & Boil well then let cool & drink once a day & 1 \\
\hline $\begin{array}{l}\text { Adansonia digitata } \\
\text { (Bombacacées) }(4,7 \%)\end{array}$ & Tohaiga & bark & Pile, add clean water and sift & $\begin{array}{l}\text { Faire boire l'animal } 1 \\
\text { à } 2 \text { fois par jour }\end{array}$ & $1-2$ \\
\hline
\end{tabular}

To fight against AAT, conventional trypanocide drugs used in this study are similar to those used by farmers in Mouhoun river basin in Burkina Faso [21]. In traditional therapy, the trypanocidal plants most used by our farmers are Balanites aegyptiaca, Capparis sepiaria, Vitellaria paradoxa, Guiera senegalensis and Mitragyna inermis, certainly because of their effectiveness against trypanosomes and their availability in the study area.

As the present study, several natural plants have been reported by other authors as having trypanocide effects on livestock. This is the case of the powder of the leaves or bark of Terminalia avicennioides and Ceiba pentendra by maceration by African farmers [22], the bark of Anogeissus leiocarpus [23] and Diospyros malabarica in Bangladesh [24]. In Cameroon, Ngantchou and Nono [25] identified the. trypanocidal activities of Entada abyssinica Polyalthia suaveolens, Flueggea virosa and Enantia chlorantha in humans. These findings reinforce the claim of Ngoroje and Bussman [26] on ethno-veterinary medicine which plays an important role in the management of livestock diseases in African countries. This medicine is the result of innovations generated after several years of practices and adapted to the socio-economic realities of the farmers in their rearing areas [27].

In conclusion, our study shows that farmers have knowledge of ruminant production constraints and diseases in the pastoral area of Gaongho. These farmers are holders of significant knowledge in diseases control of trypanosomosis in ruminants. Their traditional therapeutic practices contain enormous potentialities to complement the modern veterinary medicine, especially in terms of treatment cost and proximity. Hence, it is very important to carry out an inclusive reflection in order to find consistent and lasting solutions to the constraints of animal production and experimental researches to validate the efficacy of herbal therapeutic recipes proposed by the farmers. This work will allow us to develop at the end improved traditional medicines for farmers. For this, it appears imperative to develop a policy of availability and protection of natural plant species which constitute the raw material for the application of traditional veterinary medicine in the pastoral zone.

\section{Acknowledgments}

The authors would like to thank the project FCN 05-2014 of PPAAO / WAAPP of Burkina Faso for the financial support provided and farmers in the pastoral zone of Gaongho for their participation in the study.

\section{References}

[1] Adakal H., Stachurski F., Chevillon C. (2012). Tick control practices in Burkina Faso and acaricide resistance survey in Rhipicephalus (Boophilus) geigyi (Acari: Ixodidae). Exp Appl Acarol, 1-9.

[2] Vitouley H. S., Z. Bengaly, Adakal H., Sidibé I., Abbeele V. D., Delespaux J. V. (2013). epidemiosurveillance Network chemoresistance to trypanocidal and acaricide in West Africa (RESCAO). Tropicultura, 31, 3, 53-60. 
[3] Ministère des Ressources Animales (MRA), 2011. Document du plaidoyer du sous-secteur de l'élevage. Ouagadougou. 32 pages.

[4] Vreysen, M. J., Seck, M. T., Sall, B., Bouyer J. (2013). Tsetse flies: Their biology and control using area-wide integrated pest management Approaches. Invertebr Pathol. 112, 15-25.

[5] Delespaux V.,. Geysen D, Van den Bossche P., Geerts S. (2008). Molecular tools for the rapid detection of drug resistance in animal trypanosomes. Trend. in Parasitol, 236242.

[6] Mairie de Gaongho, 2013. Etude diagnostic en vue d'élaboration du plan communal de développement de Gaongho. 97 pages.

[7] Centre for Analysis of Economic and Social Policy (CAPES) (2006). Inventory of local knowledge in Burkina Faso. Inventory of good practices and proposals for their contribution to development. Ouagadougou. p. 448 pages.

[8] Okoli C. I., H. H. Tamboura, Hounzangbe-Adote S. M. (2010). Ethnoveterinary Medicine and Management Sustainable Livestock in West Africa. Ethnoveterinary botanical medicine: herbal medicine for animal health. Eds by David R., and Katerrere Dibongi Luseba. CRC Press Taylor \& Francis Group, 6000 Broken Sound Parkway N. W., Suite 300, Boca Raton, FL 33487-2742.

[9] Gnanda I. B. (2008). Socio-economic significance of the goat Sahel Burkinabe and improving its productivity by diet. Unique Thesis, Institute of Rural Development. Polytechnic University of Bobo-Dioulasso. 210 pages.

[10] Nalule A. S., J. Mbaria M., Olila D., Kimenju W. J. (2011). Ethnopharmacological practices in management of livestock helminths by Pastoral Communities in the drylands of Uganda. Livestock Research for Rural Development 23 (2), 2011. Accessed on 07/26/2016.

[11] Chartier C., Itard J., Morel J. P., Troncy P. M. (2000). Tropical Veterinary Parasitology Accurate; "Collection French universities," Edition Tec \& Doc. p. 773.

[12] Itard, J., Cuisance, D. and Tacher, G. (2003). Trypanosomiasis: historical-geographical distribution. In Major infectious and parasitic diseases of livestock, Europe and warmer regions. Paris: Lavoisier: 2, 1607-1625.

[13] Somda B. (2014). Exploring the potential use of salivary antigens of tsetse fly for the development of a biomarker of exposure of cattle to bites by tsetse flies and identification of salivary candidate vaccine antigens. $\mathrm{PhD}$ thesis at the University of Ouagadougou. p. 162.

[14] Boly H, Thombiano D, Humblot P, Thibier M., 1991. Influence de Trypanosoma congolense sur la fonction sexuelle de taurins Baoulé. Revue d'Elevage et deMédecine Vétérinaire des Pays Tropicaux, 44: 475-480.
[15] Shaw, A. P. M., 2004. The economics of African trypanosomiasis. In The Trypanosomiases, eds Maudlin, I., Holmes, P. H. \& Miles, M. A. pp. 369-402. Wallingford, U.K.: CABI International.

[16] Swallow BM. 2000. Impacts of Trypanosomiasis on African Agriculture. PAAT Technical and Scientific Series 2. FAO: Rome, Italy; 52.

[17] Kamuanga M., Swallow B. M., Sigue H., Bauer B., 2001. Evaluating contingent and actual contributions to a local public good: Tsetse control in the Yale agro-pastoral zone, Burkina Faso. Ecol. Econ., 39, 115-130.

[18] Kaboré A., Tamboura H. H., Belem A. G., Traoré A. (2007). Treatments ethno veterinary digestive parasites in small ruminants in the Central Plateau of Burkina Faso. Int. J. Biol. Chem. Sci. 1 (3): 297-304, 2007.

[19] Geerts S., Holmes P. H., Diallo O., Eisler C., 2001.- African bovine trypanosomiasis: the problem of drug resistance. Trends in Parasitology, 17 (1): 25-28.

[20] Talaki E., Diallo O., Sidibé I., Belem A. M. G., Pangui L. J., 2007. Méthodes de diagnostic rapide de la résistance des trypanosomes à l'isométamidium et au diminazène sur le terrain. Revue Africaine de Santé et de Productions Animales (RASPA), 5 (1-2): 29-36..

[21] Koné N., Bouyer F., Vitouley HS, I. Sidibé, N'Goran EK, Vial L., T. Balenghien, Bouyer J. (2012). Perceptions of farmers and trypanosome risk management strategies in the river basin Mouhoun (Burkina Faso). Cahiers Agricultures, vol. 21 (6): 404-416.

[22] Ba A. (1996). Past, present and perspectives of African ethnoveterinary medicine. Rev. sci. tech. Off. int. Epiz. 1996, 15 (3), $813-826$

[23] Shuaibu M N, Wuyep P T, T. Yanagi, K. Hirayama, A. Ichinose, T. Tanaka, Kouno I. (2008) Trypanocidal activity of extracts and compounds from the stem bark of Terminalia avicennoides and. Anogeissus leiocarpus.. Parasitol Res. 102 (4): 697-703.

[24] Mahbubur Rahman A. H. M., Jamila M. (2015). An Ethnoveterinary Survey of Traditional Medicinal Plants Used by the Santal Tribe at Sadar Upazila Under Jamtala Village of Chapai Nawabganj District. Velit Acta, Vol. 1 (3): 54-69.

[25] Ngantchou I,. Nono J. J. (2004) compared trypanocides activities of some isolated natural compounds of Cameroonian medicinal plants. Pharm. Med. Trad. Afr., Vol. 3, 33-39.

[26] Ngoroje, G. N., Bussman, R. W. (2006). Herbal usage and informing consensus in ethno-veterinary management of cattle disease Among the Kikuyus (Central Kenya). Journal of ethnopharmacology, 108: 332-339.

[27] Rogers E. (2003). Diffusion of innovation. (5th Ed.). New York, NY: Free Press. 